\title{
Influence of the production fluctuation on the process energy intensity in iron and steel industry
}

\author{
Chen, D. ${ }^{a}$, Lu, B. ${ }^{\text {b. }}{ }^{,}$, Chen, G. ${ }^{c}$, Yu, W. ${ }^{b}$ \\ ${ }^{a}$ School of Civil Engineering, Anhui University of Technology, Ma'anshan, China \\ ${ }^{\mathrm{b}}$ School of Energy and Environment, Southeast University, Nanjing, China \\ 'School of Energy and Environment, Anhui University of Technology, Ma'anshan, China
}

\section{A B S T R A C T}

This paper mainly studies how the production fluctuation affects the process energy intensity in iron and steel industry. First of all, the production state is divided into five conditions according to the production volatility. Meanwhile, the process energy intensity model is constructed. And model analysis showed that operating rate and qualification rate are two key parameters that represent the production volatility. A case study showed that the process energy intensity is inversely proportional to the normal production operating rate and qualification rate, but proportional to the operating rate in the other production states. Moreover, the production halt operating rate and normal production qualification rate significantly influence the process energy intensity in terms of production volatility. And then, some management suggestions were introduced on how to reduce the fluctuation of the process production. The application of the model is quantitative analysis methods, which can describe influence of production fluctuation on the process energy intensity. Based on this, corresponding measures are adopted for reducing energy consumption, including adjustment of production planning and strategy etc.
\end{abstract}

\section{ARTICLE INFO}

\section{Keywords:}

Iron and steel industry

Production fluctuation

Production state

Operating rate

Qualification rate

Process energy intensity

*Corresponding author:

10793192@qq.com

(Lu, B.)

Article history:

Received 24 June 2016

Revised 20 November 2016

Accepted 31 December 2016

\section{Reference}

[1] Du, T., Shi, T., Liu, Y., Ye, J.-B. (2013). Energy consumption and its influencing factors of iron and steel enterprise, Journal of Iron and Steel Research, International, Vol. 20, No. 8, 8-13, doi: 10.1016/S1006-706X(13)60134-X.

[2] Rasul, M.G., Tanty, B.S., Mohanty, B. (2007). Modelling and analysis of blast furnace performance for efficient utilization of energy, Applied Thermal Engineering, Vol. 27, No. 1, 78-88, doi: 10.1016/i.applthermaleng. 2006. 04.026.

[3] Zheng, L. (2012). A system dynamics based study of polocies on reducing energy use and energy expense for Chinese steel industry, Foreign Investment in China, No. 8, 156-157.

[4] Hasanbeigi, A., Price, L., Chunxia, Z., Aden, N., Xiuping, L., Fangqin, S. (2014). Comparison of iron and steel production energy use and energy intensity in China and the U.S, Journal of Cleaner Production, Vol. 65, 108-119, doi: 10.1016/i.jclepro.2013.09.047.

[5] Dong, L., Zhang, H., Fujita, T., Ohnishi, S., Li, H., Fujii, M., Dong, H. (2013). Environmental and economic gain of industrial symbiosis for Chinese iron/steel industry: Kawasaki's experience and practice in Liuzhou an Jinan, Journal of Cleaner Production, Vol. 59, 226-238, doi: 10.1016/i.jclepro.2013.06.048.

[6] Zhang, C.-X., Shangguan, F.-Q., Hu, C.-Q., Qi, Y.-H., Yin, R.-Y. (2010). Steel process structure and its impact on CO2 emission, Iron and Steel, Vol. 45, No. 5, 1-6, doi: 10.13228/i.boyuan.issn0449-749x.2010.05.021.

[7] Fysikopoulos, A., Papacharalampopoulos, A., Pastras, G., Stavropoulos, P., Chryssolouris, G. (2013). Energy efficiency of manufacturing processes: A critical review, Procedia CIRP 7 - Forty Sixth CIRP Conference on Manufacturing Systems 2013, Vol. 7, 628-633, doi: 10.1016/i.procir.2013.06.044.

[8] Worrell, E., Price, L., Martin, N. (2001). Energy efficiency and carbon dioxide emissions reduction opportunities in the US iron and steel sector, Energy, Vol. 26, No. 5, 513-536, doi: 10.1016/S0360-5442(01)00017-2. 
[9] Arens, M., Worrell, E., Schleich, J. (2012). Energy intensity development of the German iron and steel industry between 1991 and 2007, Energy, Vol. 45, No. 1, 786-797, doi: 10.1016/j.energy.2012.07.012.

[10] Li, Z.-P., Fan, X.-H., Yang, G.-M., Wei, J.-C., Sun, Y., Wang, M. (2015), Life cycle assessment of iron ore sintering process, Journal of Iron and Steel Research, International, Vol. 22, No. 6, 473-477, doi: 10.1016/S1006-706X(15) 30029-7.

[11] Zhou, H., Cheng, M., Zhou, M., Liu, Z., Liu, R., Cen, K. (2016). Influence of sintering parameters of different sintering layers on NOx emission in iron ore sintering process, Applied Thermal Engineering, Vol. 94, 786-798, doi: 10.1016 /j.applthermaleng.2015.09.059.

[12] Zhang, S., Worrell, E., Crijns-Graus, W., Wagner, F., Cofala, J. (2014). Co-benefits of energy efficiency improvement and air pollution abatement in the Chinese iron and steel industry, Energy, Vol. 78, 333-345, doi: 10.1016/ j.energy.2014.10.018.

[13] Liu, X., Chen, L., Qin, X., Sun, F. (2015). Exergy loss minimization for a blast furnace with comparative analyses for energy flows and exergy flows, Energy, Vol. 93, Part 1, 10-19, doi: 10.1016/j.energy.2015.09.008.

[14] Zhu, R., Zhu, J., Li, J. (2010). Development of and exploration on large-scale blast furnaces, World Iron \& Steel, Vol. 10, No. 5, 33-39, doi: 10.3969/j.issn.1672-9587.2010.05.007.

[15] Zhang, F.-M., Mao, Q.-W., Mei, C.-H., Li, X., Hu, Z.-R. (2012). Dome combustion hot blast stove for huge blast furnace, Journal of Iron and Steel Research, International, Vol. 19, No. 9, 1-7, doi: 10.1016/S1006-706X(13)60001-1.

[16] Napp, T.A., Gambhir, A., Hills, T.P., Florin, N., Fennell, P.S. (2014). A review of the technologies, economics and policy instruments for decarbonising energy-intensive manufacturing industries, Renewable and Sustainable Energy Reviews, Vol. 30, 616-640, doi: 10.1016/j.rser.2013.10.036.

[17] Musa, C., Licheri, R., Locci, A.M., Orrù, R., Cao, G., Rodriguez, M.A., Jaworska, L. (2009). Energy efficiency during conventional and novel sintering processes: The case of $\mathrm{Ti}_{-} \mathrm{Al}_{2} \mathrm{O}_{3}$-TiC composites, Journal of Cleaner Production, Vol. 17, No. 9, 877-822, doi: 10.1016/i.jclepro.2009.01.012.

[18] Ziebik, A., Lampert, K., Szega, M. (2008). Energy analysis of a blast-furnace system operating with the Corex process and CO2 removal, Energy, Vol. 33, No. 2, 199-205, doi: 10.1016/j.energy.2007.09.003.

[19] Shen, Y.S., Zong-Ming, L., Tao, Z., Fu-Sheng, Y., Hong-Ni, X., Rui-Lian, S. (2009). The new technology and the partial thermotechnical computation for air-cooled blast furnace tuyere, Applied Thermal Engineering, Vol. 29, No. 5-6, 1232-1238, doi: 10.1016/j.applthermaleng.2008.06.026.

[20] Oliveira, T.L., Assis, P.S., Leal, E.M., Ilídio, J.R. (2015). Study of biomass applied to a cogeneration system: A steelmaking industry case, Applied Thermal Engineering, Vol. 80, 269-278, doi: 10.1016/i.applthermaleng.2015. 01.002.

[21] Chen, L., Yang, B., Shen, X., Xie, Z., Sun, F. (2015). Thermodynamic optimization opportunities for the recovery and utilization of residual energy and heat in China's iron and steel industry: A case study, Applied Thermal Engineering, Vol. 86, 151-160, doi: 10.1016/i.applthermaleng.2015.04.026.

[22] Walsh, C., Thornley, P. (2012). Barriers to improving energy efficiency within the process industries with a focus on low grade heat utilization, Journal of Cleaner Production, Vol. 23, No. 1, 138-146, doi: 10.1016/i.jclepro.2011. 10.038.

[23] Yin, R. (2011). Metallurgical process engineering, Springer, Beijing, Metallurgical Industry Press, Beijing, China, doi: 10.1007/978-3-642-13956-7.

[24] Lu, Z., Cai, J., Yu, Q., Xie, A. (2000). The influences of materials flows in steel manufacturing process on its energy intensity, Acta Metallurgica Sinica, Vol. 36, No. 4, 370-378, doi: 10.3321/i.issn:0412-1961.2000.04.008.

[25] Chen, G., Cai, J.-J., Yu, Q.-B., Lu, Z.-W. (2002). The analysis of the influences of materials flows in iron and steel corporation on its energy consumption, Journal of Northeastern University (Natural Science), Vol. 23, No. 5, 459462, doi: 10.3321/i.issn:1005-3026.2002.05.014.

[26] Yu, Q.-B., Lu, Z.-W., Cai, J.-J. (2007). Calculating method for influence of material flow on energy consumption in steel manufacturing process, Journal of Iron and Steel Research, International, Vol. 14, No. 2, 46-51, doi: 10.1016/ S1006-706X(07)60026-0.

[27] Chae, S.H., Kim, S.H., Yoon, S.-G., Park, S. (2010). Optimization of a waste heat utilization network in an ecoindustrial park, Applied Energy, Vol. 87, No. 6, 1978-1988, doi: 10.1016/i.apenergy.2009.12.003.

[28] Gu, C., Leveneur, S., Estel, L., Yassine, A. (2013). Modeling and optimization of material/energy flow exchanges in an eco-industrial park, Energy Procedia, Vol. 36, 243-252, doi: 10.1016/i.egypro.2013.07.028.

[29] Schulze, M., Nehler, H., Ottosson, M., Thollander, P. (2016). Energy management in industry - A systematic review of previous findings and an integrative conceptual framework, Journal of Cleaner Production, Vol. 112, Part 5, 3692-3708, doi: 10.1016/i.jclepro.2015.06.060.

[30] Wang, Y., Li, H., Song, Q., Qi, Y. (2015). The consequence of energy policies in China: A case study of the iron and steel sector, Resources, Conservation and Recycling, Vol. 117, Part A, 66-73, doi:10.1016/j.resconrec.2015.07.007.

[31] Brunke, J.-C., Johansson, M., Thollander, P. (2014). Empirical investigation of barriers and drivers to the adoption of energy conservation measures, energy management practices and energy services in the Swedish iron and steel industry, Journal of Cleaner Production, Vol. 84, 509-525, doi: 10.1016/i.jclepro.2014.04.078.

[32] Tang, E., Shao, Y.-J., Fan, X.-G., Ye, L.-D., Wang, J. (2014). Application of energy efficiency optimization technology in steel industry, Journal of Iron and Steel Research, International, Vol. 21, Supplement 1, 82-86, doi: 10.1016/ S1006-706X(14)60126-6.

[33] Liu, X., Niu, D., Bao, C., Suk, S., Shishime, T. (2012). A survey study of energy saving activities of industrial companies in Taicang, China, Journal of Cleaner Production, Vol. 26, 79-89, doi: 10.1016/i.jclepro.2011.12.030.

[34] Chen, G. (2004). Development of process energy intensity formula under different state variables, Journal of Harbin Institute of Technology (New Series), Vol. 11, No. 6, 694-696, doi: 10.3969/j.issn.1005-9113.2004.06.025. 
[35] Yang, L. (2009). Assessment approaches to cleaner production audit with resource and energy as auditing keynote, Environmental Science and Management, Vol. 34, No. 7, 153-156, doi: 10.3969/j.issn.1673-1212.2009. $\underline{07.044}$. 


\title{
Vpliv nihanja proizvodnje na energetsko intenzivnost $v$ železarski in jeklarski industriji
}

\author{
Chen, D. ${ }^{a}$, Lu, B. ${ }^{\text {b. }}{ }^{,}$, Chen, G. ${ }^{c}, Y u, ~ W .{ }^{b}$ \\ ${ }^{a}$ School of Civil Engineering, Anhui University of Technology, Ma'anshan, China \\ ${ }^{\mathrm{b}}$ School of Energy and Environment, Southeast University, Nanjing, China \\ 'School of Energy and Environment, Anhui University of Technology, Ma'anshan, China
}

\section{POVZETEK}

Prispevek obravnava vpliv nihanja proizvodnje na energetsko intenzivnost $\mathrm{v}$ železarski in jeklarski industriji. Stanje proizvodnje je glede na nihanje proizvodnje razdeljeno na pet scenarijev. Zgrajen je model energetske intenzivnost procesa. Analiza modela pokaže, da sta stopnja obratovanja in stopnja usposobljenosti ključna parametra, ki vplivata na nihanje proizvodnje. Narejena je tudi študija primera, ki razkrije, da je energetska intenzivnost procesa obratno sorazmerna $\mathrm{z}$ normalno stopnjo obratovanja in stopnjo usposobljenosti, vendar sorazmerna s stopnjo obratovanja v drugih državah. Ugotovljeno je tudi bilo, da stopnja zaustavitve obratovanja in normalna stopnja usposobljenosti proizvodnje bistveno vplivata na energetsko intenzivnost procesa $\mathrm{v}$ smislu nihanja proizvodnje. Na podlagi ugotovitev so podani predlogi za zmanjšanje nihanja proizvodnega procesa. Model se lahko uporabi za kvantitativno analizo, ki opiše vpliv nihanja proizvodnje na intenzivnost energetske učinkovitosti procesa. S pomočjo analize se lahko sprejmejo ukrepi za zmanjšanje porabe energije, skupaj s prilagoditvijo načrtovanja proizvodnje, določitvijo strategije itd.

\section{PODATKI O ČLANKU}

Ključne besede:

Železarska in jeklarska industrija

Nihanje proizvodnje

Stanje proizvodnje

Stopnja obratovanja

Stopnja usposobljenosti

Energetska intenzivnost procesa

* Kontaktna oseba:

10793192@qq.com

(Lu, B.)

Zgodovina članka:

Prejet 24. junija 2016

Popravljen 20. novembra 2016

Sprejet 31. decembra 2016 